\title{
THE EFFECT OF LOCAL GOVERNMENT CHARACTERISTICS AND FINANCIAL INDEPENDENCE ON ECONOMIC GROWTH AND HUMAN DEVELOPMENT INDEX IN INDONESIA
}

\author{
Baldric Siregar $^{1^{*}}$, Nurna Pratiwi ${ }^{1}$ \\ ${ }^{1}$ STIE YKPN, Yogyakarta, Indonesia \\ *Corresponding author; Email: siregar@accountant.com
}

\begin{abstract}
This study is to analyze the effect of local government characteristics consisting of size, age, status, population, number of work units (SKPD), employee expenditure and leverage on local financial independence as well as its impact on economic growth (GDP) and the Human Development Index (HDI) in the districts or cities in Indonesia. The sample used in this study amounted to 1003 financial statements of the local government districts or cities in Indonesia from 2009 to 2013. Samples were selected based on purposive sampling method. Data analysis technique used is Partial Least Square (PLS). The results show that size, age, status, population, number of SKPD, and have leverage positive and significant effect on the local financial independence. Employee expenditure has a positive and insignificant effect on the local financial independence. Local financial independence has negative and significant effect on economic growth. Local financial independence has positive and significant effect on the Human Development Index.
\end{abstract}

Keywords: Local government, financial independence, gross domestic produt, human development index.

\section{Introduction}

Based on Act No. 23 year 2014 on regional government, the regions were given the authority to manage their own finance with little intervention of the central government. The financial capacity of a region can be seen on the size of local revenue (PAD). In connection with the provision of greater autonomy to the region, PAD is always regarded as one of the indicators or criteria to measure the dependence of the region to the central. But in fact, the value of PAD in most of the districts or cities in Indonesia is still very low when compared with the General Allocation Fund (DAU).

Based on Table 1 it can be seen that the average PAD districts or cities in Indonesia each year is increasing. However, the increase in PAD is still far below the DAU districts or cities. This indicates that the level of dependence of the districts or cities in Indonesia is still high for the central government. In other words, the financial independence of the districts or cities in Indonesia is still low.

\section{Agency Theory}

Jensen and Meckling (1976) describes the agency relationship is a contract in which one or more persons (principal) govern another person (agent) to perform a service on behalf of the principal and authorized agent in making the best decisions for the principal. In a public entity, agency theory consciously and unconciously has been applied in the Indonesian government. The central government is the principal and the local government acts as an agent, because local governments are accountable to the people as voters and also to the central government. Agents will try to convince the principal in certain manner because it is its obligation to please the government for people's independence.

Table 1

The Average PAD and DAU in Indonesia Fiscal Year 2009-2013

(in Million Rupiah)

\begin{tabular}{cccccccc}
\hline \multirow{2}{*}{ Year } & \multirow{2}{*}{ Number of LG } & \multicolumn{2}{c}{ District } & \multicolumn{2}{c}{ City } & \multicolumn{2}{c}{ Province } \\
\cline { 2 - 7 } & & PAD & DAU & PAD & DAU & PAD & DAU \\
\hline 2009 & 509 & 14,358 & 106,981 & 25,587 & 89,048 & 662,660 & 226,864 \\
2010 & 473 & 41,819 & 369,001 & 87,337 & 310,986 & $1,829,170$ & 592,320 \\
2011 & 445 & 50,923 & 415,662 & 11,035 & 343,584 & $1,678,053$ & 689,974 \\
2012 & 459 & 74,159 & 514,098 & 163,267 & 444,712 & $2,828,793$ & 839,513 \\
2013 & 396 & 83,161 & 574,802 & 253,691 & 531,240 & $3,388,206$ & 942,852 \\
\hline
\end{tabular}

Source: Indonesia Statistic Center Bereau. 


\section{Independence of Local Government}

Local independence is part of a financial performance measured by local government. According to Halim (2007), local financial independence (fiscal autonomy) shows the regional power itself in financing its government activities, development and service to its people who have to pay taxes and levies as a source of revenue required region.

\section{Characteristics of Local Government}

Special characteristics refer to having a characteristic (specificity) in accordance with a certain disposition that distinguish one thing to another (Poerwadarminta, 2006). Thus, the characteristics of local government is a picture in which a local government has special characteristics that distinguish itself with another local government.

\section{Size of Local Government}

The size of local government can be seen from how much total assets it has. Santoso's study (2015) shows that the variable size positively effects on the performance of local government. Imawan's research results (2013) and Kuncahyono's research (2015) indicate that the variable size has also positive and significant impact on the financial independence of local government. Since the growth of local government is getting bigger, it is expected that the services provided to the community will be better. So the performance of the government will also increase due to resources and adequate facilities owned by the government. Based on the analysis above, it can be developed a hypothesis:

$H_{I}$ : Size of local government has positively effect on its financial independence.

\section{Age of Local Government}

Administrative age of local government is the establishment of a local government under the Act. Research conducted by Kuncahyono (2015) shows that age doesn't affect the local government financial independence, while Santoso's research (2015) shows that the age of local government has significant and positive effect on the performance of local government. The longer or getting older means a local government already has vast experience in managing the region. The experience question is how the local government run administrative systems. The more experienced a local government, it is expected that the administration process can run effectively and efficiently to increase the income of a region. Based on the analysis above, it can be developed a hypothesis:

$H_{2}$ : Age of local government has positively effect on its financial independence.

\section{Status of the Local Government}

The status is a national recognition of a region as a county or city. County or city is the division of administrative regions in Indonesia after the province. Generally, either the district or city has the same authority that is set up and taken care of its own government. Region status in this study is used to distinguish between the city and county. Kuncahyono's study (2015) shows that the region's status has a positive effect either partially or simultaneously toward financial independence. The better the existing resources, it is expected to increase the government's performance to be better. Good government performance will certainly improve the community. Based on the analysis above, it can be developed a hypothesis:

$H_{3}$ : Status of local government has positively effect on its financial independence.

\section{Population}

According to Chairany (2010), population are all people who live in geographic regions of Indonesia for six months or longer, and those who live less than six months but aims to settle. Residents in a region certainly has a different role. Residents can become consumers and producers. The larger the population means that the level of demand and supply will increase and benefit many parties; in other words, the greater number of people will increasingly drive the various economic activities in a region. Through these economic activities, it will increase the levy into the local treasury in the form of taxes or levies. Taxes and levies are sources of local revenue to support the creation of financial independence. Based on the analysis above, it can be developed a hypothesis:

$H_{4}$ : The population has a positive effect on the financial independence of local government.

\section{Number of Regional Work Units}

Work Units (SKPD) are employees of the local government who sre empowered to authorize financial management, especially on the use of budget/ goods in the region. By using the budget/goods, certainly regions have to provide services to the community. Santoso's study (2015) shows that the 
number of SKPD has positive effect on the performance of local government. Kuncahyono's research results (2015) shows that the number of SKPD has positive and significant impact on financial independence. Based on the analysis above, it can be developed a hypothesis:

$H_{5}$ : Number of SKPD has the positive effect on the financial independence of local government.

\section{Employee Expenditure}

According to Government Regulation No. 21 year 2004 on the preparation of the Plan Budget Ministry/ agency, employee expenditures are compensated either in cash or in any form stipulated by legislation given to government employees. Employee expenditure includes operating expenses, maintenance of public infrastructure. The amount of employee expenditure is to boost the productivity performance of the employees and improve local public service. Based on the analysis above, it can be developed a hypothesis:

$H_{6}$ : Employee expenditure has positive effect on the financial independence of local government.

\section{Leverage}

Leverage refers to the company's debt. In the public sector entities, especially local government, the leverage ratio is used to measure the ratio between the debt for equity. Local governments that have a large debt will cause its financial independence of local government to be low. According to Hadi (2010), the leverage ratio of the region depends on external funding sources. Research conducted by Hadi (2010) shows that there is a relationship between leverage with local financial independence. Based on the analysis above, it can be developed a hypothesis:

$H_{7}$ : Leverage has negative effect on the financial independence of local government.

\section{Economic Growth}

Economic growth is a process of making a country's economy be sustainable or in a better condition. Economic growth is one of the indicators used to evaluate the development or progress of economic development in a region at a certain period. The economic growth rate is calculated from the change in Gross Domestic Product (GDP) at constant prices from year to year. Independent Local Government refers to the region that is able to allocate more efficiently; thereby, it is able to increase the potential of its economic activities as much as possible. With the improvement in economic activity in a region is expected to increase its economic growth. Based on the analysis above, it can be developed a hypothesis:
$H_{8}$ : Financial Independence of local government has positive effect on economic growth.

\section{Human Development Index}

One gauge is considered to reflect the status of human development is the Human Development Index (HDI). HDI is a composite index that includes three regions of human development which is considered to be very basic, the age of life, knowledge and a decent standard of living. Autonomous region means the region is able to finance its own activities of government, regional development and service to the community that will create human development. The success rate of human development as the goal of regional development can be seen from the achievement of the Human Development Index. The more independent a region, it is expected to have more prosperous society. Human Development Index can be used to measure the welfare of people in a region. Based on the analysis above, it can be developed a hypothesis:

$H_{9}$ : Financial Independence of local government has a positive effect on the Human Development Index.

\section{Research Method}

\section{Sample}

The data used in this research is collected and processed from the financial statements of local government. Selection of the sample used purposive sampling with sample selection criteria are: (1) districts or cities in Indonesia that provides all the necessary data from years 2009 to 2013 that have been published, (2) districts or cities in Indonesia, which have an active websites. It is shown on Table 2 and Table 3.

Table 2

An Overview of Research Samples

\begin{tabular}{l}
\hline $\begin{array}{l}\text { Local government financial report (LKPD) were } \\
\text { successfully downloaded (2009-2013) }\end{array}$ \\
$\begin{array}{l}\text { Local government financial report (LKPD) of } \\
\text { provincial government }\end{array}$ \\
$\begin{array}{l}\text { Local government financial report (LKPD) of } \\
\text { district or city governments that do not have } \\
\text { financial independence and the value of employee } \\
\text { expenditure }\end{array}$ \\
$\begin{array}{l}\text { Local government doesn't provide the SKPD data } \\
\text { LKPD district/city government that doesn't } \\
\text { havevalue of total assets and leverage }\end{array}$ \\
$\begin{array}{l}\text { Local government doesn't provide the GDP and } \\
\text { HDI data }\end{array}$ \\
$\begin{array}{l}\text { Local government doesn't provide the data of } \\
\text { population }\end{array}$ \\
LKPD district/city government used in the study \\
\hline
\end{tabular}


Table 3

Descriptive Statistics

\begin{tabular}{lccccc}
\hline Variable & $\boldsymbol{N}$ & Minimum & Maximum & Mean & Std. Deviation \\
\hline UKU & 1003 & $45,310,495,830$ & $292,375,440,116,392$ & $2,550,150,510,665$ & $9,544,370,385,217$ \\
UMR & 1003 & 1 & 63 & 39 & 23 \\
STS & 1003 & 203 & 800 & - & - \\
JMP & 1003 & 15,062 & $4,923,916$ & 573,391 & 633,862 \\
JMS & 1003 & 7 & 85 & 42 & 13 \\
BLP & 1003 & 0.145 & 0.798 & 0.533 & 0.118 \\
LVE & 1003 & $5.208 \mathrm{E}-14$ & 2.193 & 0.014 & 0.0850 \\
KKD & 1003 & 0.004 & 0.714 & 0.076 & 0.067 \\
PED & 1003 & -21.830 & 173.130 & 8.111 & 11.620 \\
HDI & 1003 & 0.4 & 80.51 & 69.844 & 11.889 \\
\hline
\end{tabular}

Source: Secondary data was processed.

Remarks: STS (status) are included in the table is the number of 800 district status and the status of the town of 203. UKU (Size) measured by total assets; UMR (Age) measured from the formation of a Local Government until the year of observation; STS (Status) was measured with a score of 1 and 0; JMP (Population) measured by population projections; JMS (Total SKPD) is measured by the number of sectors in a Local Government; BLP (personnel expenditures) was measured by comparison of personnel expenditure to shopping regions; LVE (Leverage) measured by the ratio of debt to equity; KKD (Financial Independence) was measured by comparison of revenue and total revenue; PED (Growth) was measured by the GDP; HDI (Human Development Index) measured by the HDI of data.

\section{Result and Discussion}

\section{Calculation of Goodness of Fit Model Value (Inner Model)}

The analysis used in this study includes the calculation of the value of goodness of fit models (inner model), and hypotheses testing using Partial Least Square analysis (PLS). Evaluation of the value of goodness of fit model serves to determine the suitability of a model used in the study shown on Table 4.

\section{Table 4}

\section{Goodness of Fit Model}

\begin{tabular}{ll}
\hline APC $=0.166, P<0.001$ & Good if $P<0.05$ \\
ARS $=0.164, P<0.001$ & Good if $P<0.05$ \\
AVIF $=1.417$ & Good if $<5$ \\
\hline
\end{tabular}

Based on Table 4, the value of $R$-squared Average (ARS) obtained the results of 0.164 with a value of $p<0.001$, this shows that the variables in this study are only able to affect the dependent variable of $16.4 \%$ and $83.6 \%$ caused by other variables outside the model. The value of Average path coefficient (APC) is 0.166 with $p<0.001$ meaning the endogenous and exogenous variables have a cause and effect relationship either directly or indirectly. There is no multicolinearity in this study as the value of Average Variance Inflation Factor (AVIF) amounted to 1.417. Interpretation of the indicators is fit with the model criteria in in this study so the research model can be used.
After testing the structural model or the inner model, the results are shown on Table 5 and Figure 1. Based on the result of hypothesis testing against the local government measure of local financial independence, it shows that the value of the path coefficient is positive value of 0.219 and $p$-value of $<0.001$ or smaller than the standard specified $p$-value $(\leq 5 \%)$. The first hypothesis test result in this study is proved that the size of the local government which is viewed from total assets. Then a local government is able to empower the region. The result of this study is consistent with the researches of Imawan and Wahyudin (2013) and Kuncahyono (2015) which show that the size of the local government has significant positive effect on financial independence.

Based on the result of the second hypothesis test, the age of the regional government has a positive and significant impact on the financial independence of the district or city in Indonesia. Hypothesis test result shows the path coefficient value of 0.06 and a $p$-value of 0.03 , which mean that the age of the regional government of positive and significant impact on the local financial independence. The result of this study does not support Kuncahyono's study (2015) which shows that the age of the local government doesn't affect the financial independence.

Based on the statistical test of the local government status of local financial independence, it shows that the value of the path coefficient is positive value of 0.367 and $p$-value of $<0.001$ or smaller than the standard specified $p$-value $(\leq 5 \%)$. The third hypothesis test in this study can be concluded that the 
Table 5

Hypotheses Testing Results

\begin{tabular}{cccccc}
\hline Hypothesis & Variable Relations & Path Coefficient & $\boldsymbol{p}$-Values & Significant/Not Significant & Result \\
\hline$H_{l}$ & UKU $\rightarrow$ KKD & 0.219 & $<0.001$ & Significant & Accepted \\
$H_{2}$ & UMR $\rightarrow$ KKD & 0.059 & $0.031^{*}$ & Significant & Accepted \\
$H_{3}$ & STS $\rightarrow$ KKD & 0.367 & $<0.001$ & Significant & Accepted \\
$H_{4}$ & JMP $\rightarrow$ KKD & 0.362 & $<0.001$ & Significant & Accepted \\
$H_{5}$ & JMS $\rightarrow$ KKD & 0.099 & $<0.001$ & Significant & Accepted \\
$H_{6}$ & BLP $\rightarrow$ KKD & 0.004 & 0.455 & Not Significant & Rejected \\
$H_{7}$ & LVE $\rightarrow$ KKD & 0.052 & $0.048^{*}$ & Significant & Rejected \\
$H_{8}$ & KKD $\rightarrow$ PED & -0.099 & $<0.001$ & Significant & Rejected \\
$H_{9}$ & KKD $\rightarrow$ IPM & 0.234 & $<0.001$ & Significant & Accepted \\
\hline
\end{tabular}

Significant at the $p$-value $\leq 5 \%$

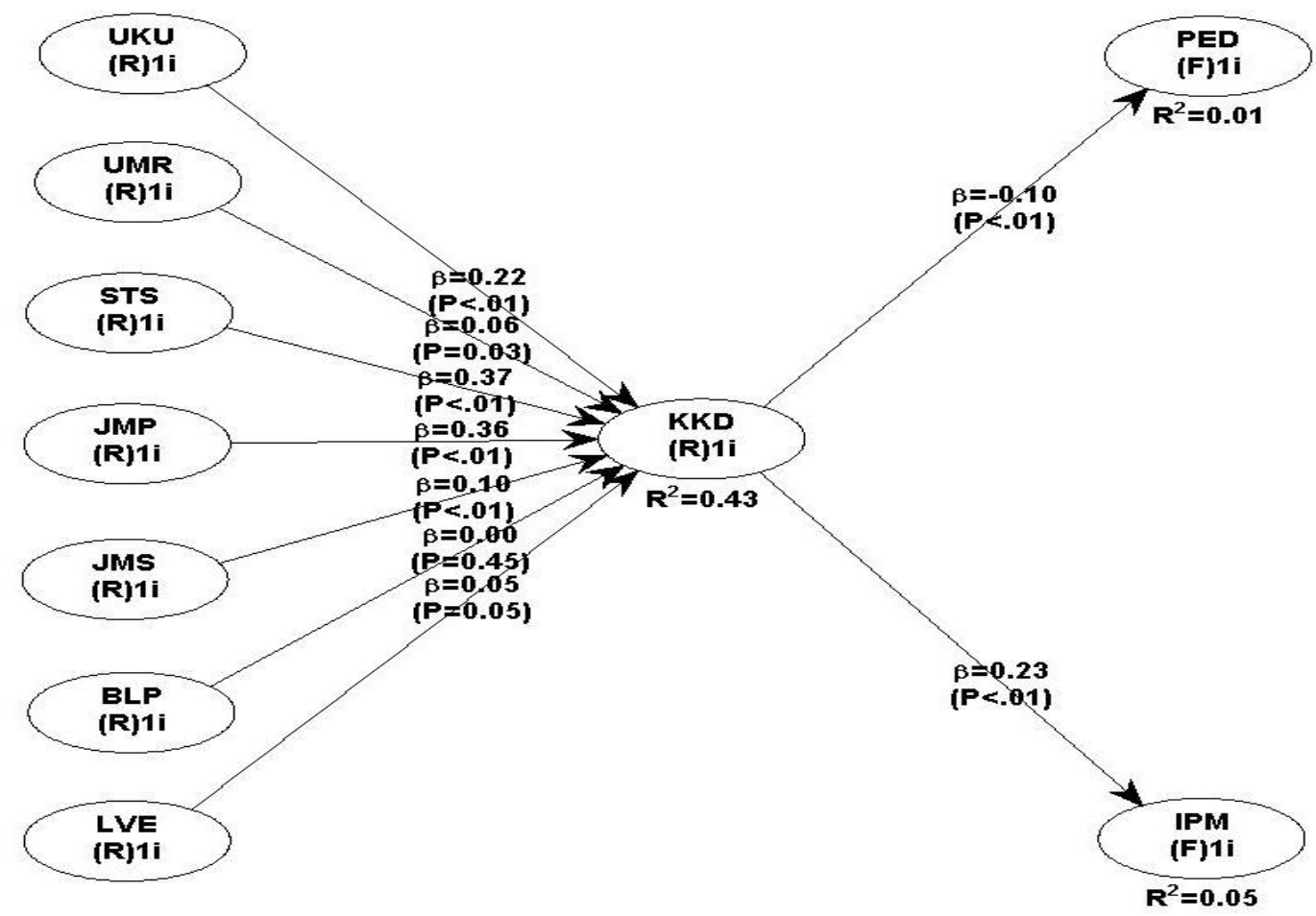

Figure 1. Hypothesis Test Results

status of the local government has positive and significant impact on the local financial independence. The result of this study is consistent with Kuncahyono's research (2015) which indicates that the status of the local government has positive and significant impact on the local financial independence.

Based on the result of the fourth hypothesis test, the number of population has positive and significant impact on the financial independence of the district or city in Indonesia. Hypothesis test results show the path coefficient value of 0.362 and $p$-value of $<0.001$, which mean that the number has positive and significant impact on the local financial independence.

Based on the result of the statistical test of SKPD number of local financial independence, it shows that the value of the path coefficient is positive value of 0.099 and $p$-value of $<0.001$ or smaller than the standard specified $p$-value $(\leq 5 \%)$. The fifth hypothesis test result can be concluded that the number of SKPD has significant positive impact on the local financial independence. This is consistent with Kuncahyono's (2015) research which shows that the number of SKPD has positive and significant impact on the local financial independence.

Based on the result of the sixth hypothesis test, personnel expenses have positive and insignificant effect on the financial independence of the district or city in Indonesia. The sixth hypothesis that employee expenditure has positive effect on local financial independence was rejected. Hypothesis test shows the 
path coefficient value of 0.004 and $p$-value of 0.455 . It differs from the researches of Kuncahyono (2015) and Darwis (2015) which show that personnel expenditures have negative and significant effect on the local financial independence.

Based on the result of the seventh hypothesis test, leverage has positive effect on the financial independence of the district or city in Indonesia. Hypothesis test shows the path coefficient value of 0.052 and $p$-value of 0.048 , which mean that leverage has positive and significant effect on local financial independence. The result is consistent with research of Hadi (2010) and Susanto, Eliza and Murtini (2015), which indicate that the leverage effect on financial independence. However, the result of this study does not support research of Imawan (2013) which shows that leverage has negative and insignificant effect on the local financial independence. The results show that the higher the leverage, the government becomes more independent. It may occur because the local government is good on managing the debt for public service purposes, so that the public service is increasingly very well.

Based on the result of hypothesis testing, it turns local financial independence has significant and negative effect on economic growth. The value of the path coefficients is negative value of 0.099 and $p$ value of $<0.001$ or smaller than the standard specified $p$-value $(\leq 5 \%)$. It can be concluded that higher level of economic growth doesn't directly affect the increase in local financial independence. It can happen because the district government doesn't maximize their potential. It does not support the researches of Hamzah (2008) and Astuti (2015) which indicate that the independence ratio has positive and significant effect on economic growth. However, it is consistent with the researches of Apriana and Suryanto (2010) and Tahar and Zakhiya (2011) which show that the region's autonomy does not significantly influence on economic growth.

Based on the result of the ninth hypothesis test, local financial independence has positive and significant effect on the Human Development Index. Hypothesis test result shows the path coefficient value of 0.234 and $p$-value of $<0.001$. It is consistent with the researches of Hidayahwati (2011) and Amalia and Nice (2014) which indicate that the local financial independence has positive and significant effect on the Human Development Index.

\section{Conclusions and Implications}

The size, age, status, population, number of SKPD, and leverage of local government have posi- tive and significant impacts on the local financial independence. Employee expenditure has positive and insignificant effect on the local financial independence while local financial independence has negative effect and significant on economic growth. Local financial independence has positive effect on the Human Development Index. It is expected to be used as a benchmark in order to maximize the potency of the characteristics possessed by the government of districts or cities in Indonesia. One way to maximize it is by increasing local revenues in order to reduce dependency on the central government. The limitation of this study is only to use data from the years of 2009-2013 year. This is due to the fact that 2014 and 2015 data are not yet available completely. Using newer observational data can provide a more update characteristics of local government, financial independence, economic growth, and Human Development Index. Future studies are expected to add years of observations to more recent years so that it can obtain the latest results on the characteristics of local government, financial independence, economic growth and Human Development Index.

\section{References}

Astuti, W. (2015). Effect of financial performance analysis of the economic growth and impact on unemployment and poverty. STIEB BANK, 6(1), $1-18$.

Chairany, M. (2010). Analisis jumlah penduduk Kecamatan Padang Bolak pada tahun 2012. Tugas Akhir. Universitas Sumatera Utara, Medan.

Darwis, E. T. R. (2015). Pengaruh belanja modal dan belanja pegawai terhadap tingkat kemandirian keuangan daerah pada kabupaten/kota Provinsi Sumatera Barat. Karya Ilmiah. Universitas Negeri Padang, Padang.

Hadi, W. (2010). Pengaruh likuiditas dan leverage terhadap kemandirian daerah (Studi terhadap laporan keuangan pemerintahan daerah tahun anggaran 2007 di wilayah Provinsi Aceh), Jurnal telaah \& Riset Akuntansi, 3(1), 29-51.

Halim, A. (2007). Akuntansi keuangan daerah. Jakarta: Salemba Empat.

Hamzah, A. (2008). Analisa kinerja keuangan terhadap pertumbuhan ekonomi, pengangguran dan kemiskinan: Pendekatan analisis jalur (Studi pada 29 kabupaten dan 9 kota di Provinsi Jawa Timur periode 2001-2006). Tugas Akhir. Universitas Trunojoyo.

Imawan, R. \& Wahyudin, A. (2013). Analisis kemandirian keuangan daerah Provinsi Jawa Tengah tahun anggaran 2010-2012. Accounting Analysis Journal, 3(2), 147-155. 
Jensen, M. C. \& Meckling, W. H. (1976). Theory of the firm: Managerial behavior, agency and ownership structure. Journal of Financial Economics, 3(4), 305-360.

Kuncahyono, H. (2015). Pengaruh karakteristik pemerintah daerah terhadap kemandirian keuangan pada pemerintah daerah di Jawa Timur. Tesis. Universitas Sebelas Maret.

Poerwadarminta. (2006). Kamus umum bahasa Indonesia. Edisi Ketiga. Jakarta: Balai Pustaka.

Santoso, D. P. (2015). Pengaruh karakteristik pemerintah daerah terhadap pendapatan asli daerah (Studi empiris: Pemerintah daerah kabupaten/kota di Propinsi Jawa Timur). Tesis. Universitas Sebelas Maret.
Susanto, E. D. \& Murtini, H. (2015). Karakteristik pemerintah daerah pendorong kemandirian keuangan daerah di Jawa Tengah. Accounting Analysis Journal, 4(4), 1-9.

Tahar, A. \& Zakhiya, M. (2011). Pengaruh pendapatan asli daerah dan dana alokasi umum terhadap kemandirian daerah dan pertumbuhan ekonomi daerah. Jurnal Akuntansi dan Investasi, 12(1), 88-99. 